SALAM; Jurnal Sosial \& Budaya Syar-i

FSH UIN Syarif Hidayatullah Jakarta

Vol. 6 No. 1 (2019), pp.97-112, DOI: 10.15408/sjsbs.v6i1.10551

\title{
Penyelesaian Satu Atap Perkara Judicial Review Di Mahkamah Konstitusi*
}

(One-Roof Settlement on the Case of Judicial Review in the Constitutional Court)

\author{
Muhammad Ishar Helmi ${ }^{1}$ \\ Pusat Studi Konstitusi dan Legislasi Nasional (Poskolegnas) \\ Universitas Islam Negeri Syarif Hidayatullah Jakarta
}

doi $10.15408 /$ sjsbs.v6i1.10551

\begin{abstract}
.
After the integration of the judiciary, the Supreme Court has a very large responsibility which previously only managed judicial techniques (examining, adjudicating and deciding cases) and administration at the Supreme Court level, but after that the Supreme Court had to manage judicial and organizational techniques, administration, and the finance in the Supreme Court and the Judicial Agency below is supplemented by the authority of judicial review of legislation under the Act. However, with unification, cassation and authority judicial review can lead to accumulation of cases in the Supreme Court, so that this is contrary to the principle of fast justice and low costs and legal certainty will be ruled out. In addition, cases of judicial review at the Supreme Court also exclude the principle of audi et alteram partem, namely the statement heard by the parties in the trial, while the proceedings in the Supreme Court do not adhere to the principle as in the Constitutional Court which is open to the public.
\end{abstract}

Keywords: Judicial Review, Audi et Alteram Partem, Constitutional Court.

\begin{abstract}
Abstrak.
Setelah adanya penyatuatapan lembaga peradilan, Mahkamah Agung memiliki tanggung jawab yang sangat besar yang sebelumnya hanya mengelola teknis yudisial (memeriksa, mengadili, dan memutus perkara) dan administrasi di tingkat Mahkamah Agung, akan tetapi setelah itu Mahkamah Agung harus mengelola teknis yudisial dan organisasi, administrasi, serta finansial di Mahkamah Agung dan Badan Peradilan di bawahnya ditambah lagi dengan kewenangan judicial review peraturan perundang-undangan di bawah Undang-Undang. Namun, dengan penyatuatapan, kasasi dan kewenagan judicial review dapat mengakibatkan menumpuknya perkara di Mahkamah Agung, sehingga hal tersebut bertentangan dengan asas peradilan cepat dan biaya ringan serta kepastian hukum akan dikesampingkan. Selain itu, perkara judicial review di Mahkamah Agung juga mengenyampingkan prinsip audi et alteram partem yakni keterangan didengarkan oleh para pihak di dalam persidangan, sedangkan proses persidangan dalam Mahkamah Agung tidak menganut prinsip seperti di Mahkamah Konstitusi yang bersifat terbuka untuk umum.
\end{abstract}

Kata Kunci: Judicial Review, Audi et Alteram Partem, Mahkamah Konstitusi

* Diterima: 22 September 2018, Revisi: 21 Desember 2018, Dipublikasi 02 Februari 2019.

1 Muhammad Ishar Helmi adalah Dosen Bidang Hukum Tata Negera pada Fakultas Syariah dan Hukum UIN Syarif Hidayatullah Jakarta. E-mail: izharhelmi@uinjkt.ac.id. 


\section{Pendahuluan}

Sejak tahun 1999, Indonesia telah memberlakukan sistem kekuasaan kehakiman menjadi satu atap (one roof system). Hal ini secara tegas diatur dalam Undang-Undang Nomor 35 Tahun 1999 tentang Kekuasaan Kehakiman, kemudian konsep satu atap lebih lanjut dijelaskan dalam Undang-Undang Nomor 4 Tahun 2004 tentang Kekuasaan Kehakiman dan Undang-Undang Nomor 5 tahun 2004 tentang Perubahan atas Undang-Undang Nomor 14 tahun 1985 tentang Mahkamah Agung. Selanjutnya, diterbitkanlah Keputusan Presiden Nomor 21 Tahun 2004 untuk pengalihan administrasi kekuasaan Kehakiman dari Pemerintah ke Mahkamah Agung. ${ }^{2}$

Pemberlakuan sistem satu atap pada kekuasaan kehakiman di Indonesia memiliki dampak tersendiri, yaitu salah satunya adalah lahirnya Mahkamah Konstitusi yang berpengaruh besar terhadap kewenangan judicial review atau pengujian peraturan perundang-undangan di Indonesia. Mahkamah Konstitusi saat itu merupakan bagian dari pelaksana kekuasaan kehakiman yang memiliki tugas melakukan Judicial Review, peninjauan dan atau pengujian kembali terhadap putusan badan legislasi dan atau eksekutif. ${ }^{3}$

Sebelumnya, kewenangan judicial review hanya diberikan kepada Mahkamah Agung sebagai satu-satunya lembaga dalam kekuasaan yudikatif saat itu. Pada perkembangannya setelah adanya Mahkamah Konstitusi, kewenangan yang dimiliki Mahkamah Agung mengenai judicial review masih tetap ada. Akan tetapi, adanya pemisahan antara kewenangan judicial review yang dimiliki keduanya. Mahkamah Agung hanya memiliki kewenangan judicial review peraturan perundang-undangan dibawah Undang-Undang terhadap Undang-Undang4, sedangkan Mahkamah Konstitusi memiliki kewenangan judicial review Undang-Undang di bawah Undang-Undang Dasar terhadap Undang-Undang Dasar. ${ }^{5}$

\footnotetext{
${ }^{2}$ Lihat https://www.hukumonline.com/berita/baca/hol10029/penyatuan-atap-kekuasaankehakiman-tuntas-sebagian.

${ }^{3}$ Nurul Qamar, Kewenangan Judicial Review Mahkamah Konstitusi, Jurnal Konstitusi, Vol. 1 No. 1, November 2012, h. 2.

${ }^{4}$ Lihat pasal 24A ayat (1), menegaskan bahwa "Mahkamah Agung berwenang mengadili dalam tingkat kasasi, menguji peraturan perundang-undangan dibawah undang-undang dan mempunyai kewenangan lain yang diberikan didalam undang-undang", adapun peraturan dibawah undang-undang yakni mengenai Peraturan Pemerintah (PP), Peraturan Presiden (Perpres), Peraturan Daerah (Perda), dan Peraturan yang dibuat oleh lembaga negara lain.

${ }^{5}$ Lihat pasal 24C ayat (1), menegaskan bahwa "Mahkamah Konstitusi berwenang mengadili pada tingkat pertama dan terakhir yang putusannya bersifat final untuk menguji undang-undang terhadap Undang-Undang Dasar, memutus sengketa kewenangan lembaga negara yang kewenangannya diberikan
} 
Selanjutnya, di dalam diri Mahkamah Agung sendiri adanya penyatuatapan lembaga peradilan dibawahnya. Setelah adanya reformasi peradilan, Mahkamah Agung memiliki tanggung jawab yang sangat besar yang sebelumnya hanya mengelola teknis yudisial (memeriksa, mengadili, dan memutus perkara) dan administrasi di tingkat Mahkamah Agung, namun setelah itu Mahkamah Agung harus mengelola teknis yudisial dan organisasi, administrasi, serta finansial di Mahkamah Agung dan Badan Peradilan di bawahnya. ${ }^{6}$

Sejak saat itu, Mahkamah Agung menjadi salah satu lembaga negara terbesar di antara lembaga negara yang lain. Adapun permasalahan yang muncul setelah penyatuatapan, yakni belum tersedianya sistem organisasi, administrasi dan finansial yang dapat mengintegrasikan sistem di Mahakamah Agung dan empat badan peradilan. Solusi yang dilakukan Mahakamah Agung ternyata hanya bersifat menggabungkan organisasi yang ada di Mahakamah Agung dan badan peradilan, bukan membangun sistem organisasi yang terintegrasi dan komprehensif sebagai konsekuensi diterapkannya sistem satu atap. Hal ini tentu saja bertentangan dengan tujuan lain dari pemberlakuan sistem satu atap, yaitu pengelolaan badan peradilan dapat lebih efisien dan efektif. Akibatnya, penggabungan Mahakamah Agung dan empat badan peradilan menimbulkan membengkaknya organisasi dan berlakunya banyak sistem yang menimbulkan tumpang tindih kewenangan dan fungsi kerja serta keruwetan pengelolaan Mahakamah Agung.

Selain masalah yang disebutkan diatas, sekilas terlihat bahwa dengan adanya pembagian kekuasaan judicial review dari dua lembaga yakni Mahkamah Konstitusi dan Mahkamah Agung tidak memberikan dampak hukum apa-apa justru dapat mencegah adanya penumpukan perkara yang tentu saja berdampak pada kekosongan hukum. Meski sudah lama masalah penyatuatapan mengenai judicial review di sarankan untuk di tangani oleh Mahkamah Kostitusi, akan tetapi saran tersebut di anggap angin lalu dan tidak adanya kejelasan mengenai masalah penyatuatapan tersebut. Adapun dasar ide dari dibentuknya judicial review yaitu mengenai cara pembentukan dari peraturan perundang-undang agar tetap sejalan dengan norma hukum yang berlaku di Indonesia yakni dengan

oleh Undang-Undang Dasar, memutus pembubaran partai politik dan memutus perselisihan tentang hasil pemilihan umum".

${ }^{6}$ Kamaruddin, Diskursus Penyatu Atapan Peradilan Agama Di Bawah Mahkamah Agung (Studi Hukum Responsif), Jurnal AL-'Adl Vol. 8 No. 1, Januari 2015, h.59-60. 
tidak bertentangan dengan aturan yang diatasnya yaitu groundnorm. ${ }^{7}$ Dibentuknya lembaga Mahkamah Konstitusi yakni dalam rangka penyempurnaan sistem kewenangan judicial review, akan tetapi pada kenyataannya pengaturan tersebut justru rentan menimbukan berbagai polemik hukum baru.

\section{Keberadaan Kekuasaan Kehakiman Pasca Reformasi}

Kekuasaan kehakiman merupakan pilar ketiga dalam tatanan negara modern, fungsi kekuasaan ketiga ini sering di sebut cabang kekuasaan yudikatif. Dalam sistem negara yang modern, cabang kekuasaan kehakiman diorganisasikan secara tersendiri. ${ }^{8}$

Keinginan untuk melahirkan sistem konstitusionalisme, mendorong perubahan terhadap konstitusi. Perubahan atau amandemen konstitusi membawa perubahan besar dalam sistem ketatanegaraan terutama pasca reformasi. Salah satu perubahan tersebut yakni diaturnya lembaga Mahkamah Konstitusi (MK), disamping Mahkamah Agung (MA). Eksistensi MK diatur dalam BAB IX Pasal 24 ayat (2) UUD 1945 yang menyatakan bahwa Kekuasaan kehakiman dilakukan oleh sebuah Mahkamah Agung dan badan peradilan dibawahnya dalam lingkungan peradilan umum, lingkungan peradilan agama, lingkungan peradilan militer, lingkungan peradilan tata usaha negara dan oleh sebuah Mahkamah Konstitusi. Berdasarkan ketentuan tersebut baik MA maupun MK berkedudukan yang setara, yakni sebagai pelaku kekuasaan kehakiman dalam tugas dan wewenang masing-masing. ${ }^{9}$

\section{Kewenangan Judicial Review}

Kewenangan MK untuk menguji Undang-Undang terhadap UndangUndang Dasar merupakan fenomena baru dalam kehidupan ketatanegaraan. Pasca dibentuknya lembaga itu, permohonan pengujian Undang-Undang semakin meningkat. Peningkatannya tersebut baik kualitatif maupun kuantitatif pengujian Undang-Undang merupakan bentuk pelaksanaan demokrasi konstitusionalisme di Indonesia, hal itu berarti kehadiran MK adalah untuk meneguhkan supremasi hukum dan kedaulatan rakyat. Negara hukum dan

7 Mahfud, MD. Mengawal Arah Politik Hukum: Dari Prolegnas sampai Judicial Review, http://www.mahfudmd.com/public/makalah/makalah_26.pdf, diakses 20 Januari 2019

8 Jimly Asshidiqie, Pengantar Ilmu Hukum Tata Negara, ( Rajawali Pers: Jakarta, 2009), h.310

9 Jimly Asshiddiqie, Kedudukan Mahkamah Konstitusi dalam Struktur Ketatanegaraan Indonesia, Makalah Kuliah Umum di Fakultas Hukum Universistas Sebelas Maret, Surakarta, 2 September 2004, h.2. 
kedaulatan rakyat merupakan dua sisi dari prinsip konstitusionalisme tersebut. Faham konstitusionalisme "bertolak dari pemikiran tentang hak-hak konstitusional yang merupakan hak-hak yang dijamin oleh konstitusi, yang dapat ditegakkan pemenuhannya melalui pengadilan."10

Berlakunya konstitusi sebagai hukum dasar menurut Jimly, didasarkan atas kekuasaan tertinggi atau prinsip kedaulatan yang dianut dalam suatu Negara, agar konstitusi benar-benar menjadi hukum tertinggi maka ketentuanketentuan dasar konstitusional yang menjadi materi muatannya harus dilaksanakan melalui perundang-undangan di bawah konstitusi. ${ }^{11}$ Peraturan perundang-undangan baik yang dibuat oleh legislatif maupun peraturan pelaksanaan yang dibuat oleh eksekutif tidak boleh bertentangan dengan konstitusi itu sendiri, apabila terjadi pertentangan kemudian memunculkan wacana tentang hak menguji (judicial review). Dalam doktrin ilmu hukum tata negara, "hak menguji dibedakan atas hak menguji formil dan hak menguji materiil."12

Mengenai kewenangan MA untuk menguji peraturan perundangundangan dibawah Undang-Undang terhadap Undang-Undang, dapat dikatakan sebagai upaya pengujian legalitas (legal review). Pengujian yang dilakukan oleh MA ini jelas berbeda dari pengujian konstitusional (constitutional review) yang dilakukan oleh Mahkamah Konstitusi. Pertama, objek yang diuji hanya terbatas pada peraturan perundang-undangan dibawah Undang-Undang (judicial review of regulation). Sedangkan pengujian atas konstitusionalitas Undang-Undang (judicial review of law) dilakukan oleh Mahkamah Konstitusi. ${ }^{13}$ Kedua, yang dijadikan batu penguji oleh Mahkamah Agung adalah UndangUndang, bukan Undang-Undang Dasar Negara Republik Indonesia Tahun 1945. Oleh karena itu, dapat dikatakan bahwa pengujian norma hukum yang dilakukan oleh MA adalah pengujian legalitas peraturan (judicial review on the legality of regulation), sedangkan pengujian oleh MK merupakan pengujian konstitusionalitas Undang-Undang (judicial review on the constitutionality of law).

10 I Dewa Gede Palguna, PengaduanKonstitusional (Constitutional Complaint) Upaya Hukum terhadap Pelanggaran Hak-hak Konstitusional Warganegara, (Sinar Grafika: Jakarta, 2013), h.113

${ }^{11}$ Jimly Asshiddiqie, Gagasan Dasar tentang Konstitusi dan Mahkamah Konstitusi dalam Butirbutir Pemikiran dalam Hukum, Memperingati 70 tahun Prof.Dr B. Arief Shiddarta, SH. Penyunting Sri Rahayu Oktoberina dan Niken Savitri,( Refika Aditama: Bandung, 2008), h.189.

12 Moh Kusnardi dan Harmaily Ibrahim, Pengantar Hukum Tata Negara Indonesia, (Pusat Studi Hukum Tata Negara Fakultas Hukum Universita Indonesia, Jakarta: 1983), h.227.

${ }^{13}$ Jimly Assiddiqie, Perkembangan dan Konsolidasi Lembaga Negara Pasca Reformasi, (Setjen dan kepaniteraan Mahkamah Konstitusi, Jakarta, 2006), h.158. 
Yang terakhir ini biasa disebut juga dengan istilah pengujian konstitusionalitas atas Undang-Undang (constitutional review of law). ${ }^{14}$ Ketiga, Pengujian yang dilakukan di MA terkadang tidak sejalan dengan putusan yang di lakukan di MK dengan artian bahwa Undang-Undang yang diputus MK terkadang masih menjadi polemik oleh MA baik dari segi waktu dan materi yang diputuskan.

Jimly Asshiddiqie menegaskan "pada intinya prinsip-prinsip pemisahan atau pembagian kekuasaan itu dimaksudkan untuk membatasi kekuasaan negara itu dari kemungkinan menjadi sumber penindasan dan tindakan yang sewenang-wenang pada penguasa." 15 Pengaturan dan pembatasan kekuasaan itu menurut Jimly yang menjadi ciri konstitusionalisme dan sekaligus tugas utama konstitusi, sehingga kemungkinan kesewenangwenangan kekuasaan dapat dikendalikan dan diminimalkan. Berkaitan dengan pembagian kekuasaan, Jimly juga membedakan antara pemisahan kekuasaan secara horizontal dalam arti kekuasaan dipisah-pisahkan ke dalam fungsi-fungsi yang tercermin dalam lembaga-lembaga negara yang sederajat dan saling mengimbangi (cheks and balences). ${ }^{16}$ Sedangkan pembagian kekuasaan yang bersifat vertikal dalam arti perwujudan kekuasaan itu dibedakan secara vertikal ke bawah kepada lembagalembaga tinggi negara di bawah lembaga pemegang kedaulatan rakyat.

\section{Dualisme Judicial Review di Indonesia}

Indonesia menganut sistem dualisme konstitusi yang mana pengujian peraturan perundang-undangan dilakukan oleh badan yudikatif yakni Mahkamah Agung dan Mahkamah Konstitusi, keduanya memiliki kesamaan dalam kewenangan yakni mengadili permohonan judicial review. Seperti yang diketahui perbedaan dalam proses persidangan mengenai pengujian peraturan terhadap Undang-Undang antara lembaga MA dan MK cukup menonjol dan bertolak antara keduanya yakni adanya perbedaan transparansi dalam proses pengadilan, yang mana persidangan di MK telah menerapkan prinsip audi et alteram partem yakni keterangan didengarkan oleh para pihak di dalam persidangan, sedangkan proses persidangan dalam MA tidak menganut prinsip seperti MK tersebut yang mana dalam pengujian Mahkamah Agung ini bersifat tertutup sehingga tidak menerapkan asas audi et alteram partem, pengujian hanya

\footnotetext{
${ }^{14}$ Jimly Assiddiqie, Perkembangan dan Konsolidasi Lembaga Negara Pasca Reformasi, h.158

${ }^{15}$ Jimly Asshiddiqie, Format Kelembagaan Negara dan Pergeseran Kekuasaan dalam UUD 1945, (UII Press, Yogyakarta, 2005), h.36.

${ }^{16}$ Erli Salia, Peran Mahkamah Konstitusi Dalam Mewujudkan Negara Hukum Yang demokratis, (Makalah, Palembang), h.6
} 
dilakukan terhadap berkas permohonan yang diajukan oleh pemohon dan berkas jawaban yang dari pihak termohon.

Hal ini justru yang menimbulkan polemik, sebagaimana diketahui bahwa peraturan perundang-undangan dibawah Undang-Undang sanggat luas cakupannya yaitu mulai dari Peraturan Pemerintah, Peraturan Presiden, Peraturan Menteri, Peraturan Lembaga, dan Peraturan Daerah provinsi/kabupaten/kota. Kasus-kasus mengenai peraturan tersebut mengakibatkan membengkaknya permohonan judicial review di MA. Adapun proses persidangan di MA selama ini telah melanggar Pasal 13 Undang-Undang Nomor 48 Tahun 2009 tentang Kekuasaan Kehakiman. Seperti yang telah di atur dan ditegaskan didalam Pasal 13 Undang-Undsng Kekuasaan Kehakiman, bahwa seluruh pemeriksaan pengadilan terbuka untuk umum dan putusan pengadilan hanya sah dan memiliki kekuatan hukum apabila diucapkan dalam sidang terbuka untuk umum. Tertutupnya proses pemeriksaan di tingkat MA hanya akan mempersulit proses pengajuan judicial review maka dari itu tidak menutup kemungkinan masyarakat nantinya akan mengajukan usul mengenai Perda diskriminatif mengenai proses pemeriksaan serta pengadilan di MA.

Proses pengujian yang selama ini dilakukan di MA telah melanggar asas independensi dan partial juga asas peradilan cepat dan biaya ringan. putusan MA yang tidak langsung berlaku akan berdampak pada tidak adanya kepastian hukum sehingga hanya akan menimbulkan penyalahgunaan kewenangan. Pada saat ini telah jelas kita lihat bahwa kewenangan yang dimiliki oleh MK dalam pengujian Undang-Undang ternyata berpelung besar dalam menggugurkan putusan perkara judicial review yang ada di MA tersebut. Penyerahan kewenangan judicial review oleh MA dan MK menyisakan kerumitan tersendiri dalam hal pengujian, yang mana peraturan perundang-undangan tidak bertentangan secara langsung dengan aturan setingkatnya akan tetapi bertentangan dengan aturan yang lebih tinggi, contohnya seperti Peraturan Pemerintah yang tidak bertentangan dengan Undang-Undang akan tetapi bertentangan langsung dengan Undang-Undang Dasar, terlepas dari siapa yang berwenang terhadap materi peraturan yang bertentangan dengan materi peraturan lebih tinggi, pada nyatanya MA tidak berwenang dalam pengujian karena MA menggunakan batu uji Undang-Undang sedangkan peraturan yang hendak di uji tidak bertentangan dengan Undang-Undang terkait tetapi berkaitan dengan Undang-Undang Dasar yang mana bukanlah ranah dari Mahkamah Agung. Dan jika tetap di uji di MK bukanlah kompetensi MK tetapi 
ranah dari MA. Hal tersebut yang dapat menimbulkan kerumitan dalam penyelesaian sengketa peraturan perundang-undangan. ${ }^{17}$

\section{Pengujian Satu Atap Peraturan Perundang-Undangan di Mahkamah Konstitusi}

Secara teori tidak terdapat hubungan antara MK dan MA, karena kedua lembaga tersebut memiliki objek kewenangan yang berbeda dalam hal kewenangan judicial review. Sehingga sepintas terlihat kondisi ini tidak adanya hubungan diantara kedua lembaga tersebut. namun harus kita pahami sebelumnya, bahwa kewenangan dua lembaga tersebut berada dalam satu jenjang hirarki perundang-undangan, yakni: a). Undang-Undang Dasar 1945, b) Tap MPR, c) Undang-Undang/PERPU, d) Peraturan Pemerintah, d) Peraturan Presiden, e) Perda Provinsi, f) Perda Kab/kota. ${ }^{18}$ Dengan demikian segala peraturan perundang-undangan wajib tunduk kepada peraturan perundangundangan di atasnya kalaupun pada akhirnya ditemukan suatu peraturan undang-undang yang bertentangan dengan peraturan perundang-undang diatasnya, maka disinilah perlu adanya pengujian agar terciptanya keselarasan dalam peraturan perundang-undangan.

Gagasan penyatuatapan pengujian peraturan perundang-undang dalam jangka panjang dapat diupayakan berkesinambungan (including of law and justice). Kehadiran MK dengan tugas pokok dan fungsinya adalah dalam rangka memperkuat prinsip negara hukum, demokrasi dan perlindungan hak asasi manusia. Kehadiran MK juga dapat dipandang sebagai bagian dari usaha pembaharuan sistem hukum dengan mengokohkan fundamennya pada konstitusi. Dengan demikan, tidak ada lagi Undang-Undang yang bertentangan dengan konstitusi.

Persoalan dalam hal kewenangan judicial review antara MA dan MK semakin terbuka lebar. dengan adanya ketentuan ini, maka Badan atau Pejabat Tata Usaha Negara memiliki kesempatan untuk tidak melaksanakan putusan MA seketika sejak putusan di bacakan sampai tenggang waktu 90 hari sejak pembacaan putusan. ${ }^{19}$ Dalam tenggang waktu 90 hari tersebut dimana Badan atau Pejabat Tata Usaha Negara belum menjalankan putusan terkait perkara judicial review yang dikelurakan oleh MA, sangat terbuka kemungkinan adanya

\footnotetext{
17 Janpatar Simamora, Analisis Yuridis Terhadap Model Kewenangan Judicial Review di Indonesia, Fakultas Hukum Universitas HKBP Nommensen, Vol.25, No.3, Oktober 2013, h.390

18 Pasal 7 ayat (1) Undang-Undang Nomor 12 Tahun 2011 tentang pembentukan peraturan perundang-undagan.

${ }^{19}$ Lihat Pasal 8 ayat (2) Perma Nomor 1 Tahun 2011 Tentang Uji Materi.
} 
pihak-pihak lain yang mengajukan perkara judicial review terhadap MK dengan objek persoalan ketentuan Undang-Undang yang telah dijadikan MA sebagi dasar hukum judicial review di tingkat bawahnya.

Dalam suatu negara hukum yang mengedepankan prinsip demokrasi haruslah memenuhi unsur yang relavan untuk di terapkan dalam suatu pengujian peraturan perundang-undangan yakni the supremacy of law atau supremasi hukum. Pada prinsipnya bahwa hukum harus berada di tempat yang tertinggi dalam tatanan suatu negara yang mana hukum tersebut harus dapat memberikan jaminan kepastian dan keadilan. Oleh karena itu, sangat tidak mungkin bilamana kewenangan pengujian peraturan perundang-undangan dipisah antara MK dan MA.

Dengan demikian, seharusnya lembaga peradilan yang diberikan wewenang untuk menguji peraturan perundang-undangan atau judicial review cukup satu lembaga peradilan yang menangani perkara judicial review yakni Mahkamah Konstitusi dengan tolak ukur pengujiannya adalah peraturan perundang-undang yang kedudukannya satu tingkat lebih tinggi dari objek yang diuji sampai dengan peraturan perundang-undangan yang tertinggi yakni Undang-Undang Dasar 1945.

Menurut Prof Jimly Asshidiqie, pembagian tugas pada judicial review atas peraturan perundang-undang antara MK dan MA bukan suatu yang ideal, karena dapat menimbulkan perdebatan atas putusan yang saling bertentangan antara Mahkamah Konstitusi dan Mahkamah Agung. ${ }^{20}$ Jimly Asshiddqie berpandangan idealnya kewenangan menguji peraturan perundang-undangan dibebankan kepada MK sebagai penyatuatapan pengujian undang-undang (including of law and justice); ${ }^{21}$ meskipun gagasan itu disadari olehnya bahwa tidak mudah direalisasikan karena perbedaan pengertian, konsep didasarkan kepada prinsip demokrasi yang terus dikembangkan. Namun bertolak dari prinsip bahwa MK merupakan the guardian of the constitution dan MA sebagai the guardian of the Indonesian law. MA mengawal undang-undang dan peraturan di bawahnya baik melalui pengujian maupun melalui peradilan, sedangkan MK mengawasi konstitusi. Pandangan ini berkembang lebih lanjut dengan pemikiran bahwa MK merupakan Court of Law dan MA sebagai Court of Justice. Sebagai Court of Law (court of constitution) maka putusannya bersifat final

20 Safi', Urgensi Penyatuan Kewenangan Pengujian Peraturan Perundang-undangan oleh Lembaga Peradilan (Judicial Review) Di Indonesia, Jurnal Rechtidee, Vol 11 No. 2, Desember 2016, h.218. 2006), h.66.

${ }^{21}$ Jimly Asshidiqie, Sengketa Kewenangan Antar Lembaga Negara, (Konstitusi Pers: Jakarta, 
dan mengikat (final and binding) sedangkan sebagai Court of Justice, terhadap putusan dapat dilakukan pengujian ditingkat selanjutnya, untuk tercapainya keadilan. Sementara itu MK lebih concern berusaha untuk menciptakan kesatuan tata hukum dalam negara hukum.

Ada empat alasan yang menyebabkan pemisahan pengujian peraturan tersebut menjadi tidak ideal, yaitu sebagai berikut:22 1). Pemberian kewenangan pengujian (Judicial Review), uji materi Undang-Undang terhadap UndangUndang dasar kepada MK yang baru dibentuk mengesankan hanya sebagian tambahan perumusan terhadap materi Undang-Undang Dasar secara mudah dan tambal sulam, seakan-akan konsepsi hak uji materiil peraturan yang ada di tangan MA tidak turut berpengaruh dengan hak uji yang diberikan kepada MK. Perumusan demikian terkesan seakan kurang didasarkan atas pendalaman konseptual berkenaan dengan konsepsi uji materi itu sendiri secara komprehensif; 2). Pemisahan kewenangan itu masuk akal untuk dilakukan jika sistem kekuasaan yang di anut masih didasarkan atas prinsip pembagian kekuasaan sebagaimana yang dianut oleh Undang-Undang Dasar 1945 sebelum mengalami perubahan pertama dan kedua, Undang-Undang Dasar 1945 setelah perubahan telah resmi dan tegas menganut prinsip pemisahan kekuasaan horizontal mengutamakan prinsip checks and balances. Oleh karena itu, pemisahan antara materi Undang-Undang dan materi peraturan di mahkamah konstitusi merupakan lembaga yang dibentuk guna menguji peraturan UndangUndang dibawah Undang-Undang Dasar bawah undang-undang tidak seharusnya dilakukan lagi; 3). Pada praktik pelaksanaannya nanti, secara hipotetis dapat timbul pertentangan substantif antara putusan MA dengan putusan MK. Oleh karena itu, sebaiknya sistem pengujian peraturan perundangundangan di bawah konstitusi diintegrasikan saja di bawah MK. Dengan demikian masing-masing Mahkamah dapat memfokuskan perhatian pada masalah yang berbeda. MA menangani persoalan keadilan dan ketidakadilan bagi warga negara, sedangkan MK menjamin konstitusionalitas keseluruhan peraturan perundang-undangan; 4). Jika kewenangan pengujian materi peraturan di bawah UUD sepenuhnya diberikan kepada MK, tentu beban MA dapat dikurangi.

Sedangkan dalam prespektif teori wewenang, teori politik hukum dan teori pengujian norma hukum, pilihan penyatuan kewenangan pengujian

22 Safi', Urgensi Penyatuan Kewenangan Pengujian Peraturan Perundang-undangan oleh Lembaga Peradilan (Judicial Review) Di Indonesia, Jurnal Rechtidee, Vol 11 No. 2, Desember 2016, h. 218219. 
peraturan perundang-undangan dibawah Mahkamah Konstitusi, juga didasari oleh beberapa alasan hukum sebagai berikut:23 Pertama, untuk mengurangi beban pekerjaan penanganan perkara di MA yang luar biasa banyaknya. Sehingga dengan diintegrasikannya kewenangan pengujian peraturan perundang-undangan dibawah Mahkamah Konstitusi, diharapkan Mahkamah Agung akan lebih fokus pada penanganan perkara konkrit ditingkat kasasi dan peninjauan kembali bagi para pencari keadilan (teori wewenang dan politik hukum).

Kedua, untuk memberikan kepastian dan keadilan kepada masyarakat karena tidak aka ada lagi perbedaan penafsiran atau putusan yang saling bertentangan antara Mahkamah Agung dan Mahkamah Konstitusi (teori politik hukum).

Ketiga, akan lebih efisien dan efektif dari segi waktu penyelenggaraan pengujiannya. Sehingga tidak perlu lagi ada pengaturan larangan bagi Mahkamah Agung untuk menguji suatu peraturan dibawah undang-undang manakala di Mahkamah Konstitusi sedang diuji undang-undang yang berkaitan dengan peraturan yang akan diujikan di Mahkamah Agung sebagaimana diatur dalam Pasal 55 Undang-Undnag Nomor 24 Tahun 2003 tentang Mahkamah Konstitusi, serta akan dapat lebih menjamin harmonisasi materi peraturan perundang-undangan melalui mekanisme kontrol normatif (teori pengujian norma hukum). Selain itu, Menurut hasil penelitian disertasi Zainal Arifin Hoesein, dilihat dari segi praktis efisien dan efektivitas, justru pengujian peraturan perundang-undangan oleh Mahkamah Agung berjalan sangat tidak efektif, karena rata-rata perkara yang diselesaikan per tahun antara 1.-2 (gugatan) dan 3 perkara (permohonan). Sebaliknya, Mahkamah Konstitusi justru lebih produktif, karena hanya dalam 1 (satu) tahun 1 (satu) bulan dapat menyelesaikan 22 (dua puiuh dua) perkara .

Keempat, karena dari prespektif teori wewenang dan teori politik hukum, tujuan dibentuknya serta tugas dan fungsi utama Mahkamah Konstitusi sebagaimana dijelaskan dalam Penjelasan Umum Undang-Undang Nomor 24 Tahun 2003 tentang Mahkamah Konstitusi adalah untuk menangani perkara ketatanegaraan atau perkara konstitusi tertentu dalam rangka konstitusi agar dilaksanakan secara bertanggungjawab sesuai kehendak rakyat dan cita-cita demokrasi. Keberadaan MK sekaligus untuk menjaga terselenggaranya pemerintahan negara yang stabil, dan juga merupakan koreksi terhadap

23 Safi, Urgensi Penyatuan Kewenangan Pengujian Peraturan Perundang-undangan oleh Lembaga Peradilan (Judicial Review) Di Indonesia, Rechtidee, Vol.11, No.2 , Desember 2016, h. 222. 
pengalaman kehidupan ketatanegaraan di masa lalu yang ditimbulkan oleh tafsir ganda terhadap konstitusi. Oleh karena itu, Mahkamah Konstitusi selain sebagai penjaga konstitusi (the guardian of the constitution), Mahkamah Konstitusi juga merupakan penafsir tertinggi konstitusi (the sole interpreter of constitution).

Kelima, karena hukum acara pengujian peraturan perundang-undangan di Mahkamah Konstitusi lebih terbuka dibanding dengan hukum acara pengujian peraturan perundang-undangan di Mahkamah Agung, yaitu dengan melibatkan dan mengundang pemohon, termohon, dan pihak terkait dalam setiap tahapan persidangan. ${ }^{24}$

Problem potensial akan muncul sebagai efek samping dari judicial review yang pada praktiknya dilakukan oleh dua lembaga, dalam hal ini MA dan MK. Padahal sesuai dengan prinsip hukum yang berjenjang (Stufenbau Theory), peraturan perundang-undangan akan saling kait mengait, utamanya secara vertikal. Peraturan perundang-undangan yang memiliki derajat lebih tinggi menjadi dasar dan cantolan bagi peraturan perundang-undangan di bawahnya, demikian seterusnya. Karenanya, berlaku asas lex superior derogat lex inferior dimana peraturan yang lebih rendah tidak boleh bertentangan dengan peraturan perundang-undangan yang lebih tinggi. Oleh karena dilakukan dua lembaga berbeda, tidak mustahil akan terjadi persinggungan normatif secara vertikal yang justru bersifat kontradiktif terhadap tujuan judicial review untuk menjamin harmonisasi dan tertib hukum. Sangat mungkin, dalam praktik masing-masing, kedua lembaga tersebut menggunakan tolok ukur hukum yang berbeda untuk peraturan perundang-undangan terkait yang dapat saja berujung pada putusan yang berbeda secara mencolok.

Keberadaan lembaga MK menjadi nafas dan semangat baru, bahwa cita hukum (rechtsidee) dan cita negara (staatsidee) harus dijaga. Namun cukupkah MK menjadi lembaga penafsir Undang-Undang semata, karena aturan di bawah Undang-Undang tetap tidak boleh bertentangan dengan konstitusi. Mahkamah Konstitusi sebagai lembaga peradilan tingkat pertama dan terakhir tidak mempunyai struktur organisasi sebesar Mahkamah Agung yang merupakan puncak sistem peradilan yang strukturnya bertingkat secara vertikal dan secara horizontal mencakup lima lingkungan peradilan, yaitu lingkungan peradilan umum, lingkungan peradilan tata usaha negara, lingkungan peradilan agama, dan lingkungan peradilan militer. Mahkamah Agung sudah sedemikian banyak

24 Safi', Urgensi Penyatuan Kewenangan Pengujian Peraturan Perundang-undangan oleh Lembaga Peradilan (Judicial Review) Di Indonesia, Jurnal Rechtidee, Vol 11 No. 2, Desember 2016, h.222-223. 
dibebani dengan tugas dan tanggung jawab yang luar biasa berat, yang rawan dan berpotensi menyebabkan tumpukan pekerjaan dan perkara tidak terselesaikan karena beban kerja yang overload, oleh karenanya demi agar terjadi kelancaran dan kesinambungan peradilan, alangkah baiknya jika salah satu beban MA yaitu Judicial Review, diserahkan pada MK.

Mahkamah Agung digambarkan sebagai puncak peradilan yang berkaitan dengan tuntutan perjuangan keadilan bagi orang per orang ataupun subjek hukum lainnya, sedangkan Mahkamah Konstitusi tidak berurusan dengan orang per orang, melainkan dengan kepentingan umum yang lebih luas. Perkara-perkara yang diadili di Mahkamah Konstitusi pada umumnya menyangkut persoalan-persoalan kelembagaan negara atau institusi politik yang menyangkut kepentingan umum yang luas ataupun berkenaan dengan pengujian terhadap norma-norma hukum yang bersifat umum dan abstrak, bukan urusan orang per orang atau kasus demi kasus ketidak-adilan secara individuil dan konkrit. Menegaskan bahwa MK adalah court of law, dan MA adalah court of justice. MA sebagai court of justice mengadili ketidakadilan dari subyek hukum untuk mewujudkan keadilan, sedangkan MK sebagai court of law mengadili sistem hukum untuk mencapai keadilan itu sendiri. Judicial review itu termasuk ke dalam ranah court of law dikarenakan judicial review itu tidaklah mengadili orang per orang, lembaga, organisasi, dan subyek hukum melainkan mengadili sistem hukum (perundang-undangan) demi mencapai keadilan. Oleh karenanya, berdasarkan konstruksi usulan tersebut diatas, kewenangan Judicial Review akan lebih baik dilaksanakan satu atap di Mahkamah Konstitusi.

Adapun terkait praktik pengujian peraturan perundang-undangan yang terpisah di MK (Undang-Undang) dan MA (Peraturan perundang-undangan dibawah Undang-Undang) seperti saat ini, maka berdasarkan beberapa pertimbangan sebaiknya disatukan di Mahkamah Konstitusi. Adapun argumentasi agar pengujian peraturan Perundang-undangan dilaksanakan dalam format satu atap di MK adalah sebagai berikut: 1). Pengujian peraturan perundang-undangan dua atap tentu menyulitkan para pencari keadilan (justice seeker) dalam perspektif human rights based constitutionalism; 2). Kebijakan hukum harus mempertimbangkan aspek ekonomi (efisiensi dan manfaat), sehingga proses Pengujian peraturan perundang-undanganmencerminkan asas cepat, sederhana dan biaya murah; dan 3). Pengujian peraturan perundang-undangan 
satu atap mempertegas peran Mahkamah Konstitusi sebagai the guardian of constitution. ${ }^{25}$

\section{Kesimpulan}

Dari uraian diatas, dapat diambil suatau kesimpulan yakni belajar dari pengalaman terkait dengan lahirnya persoalan hukum sehubung dengan model kewenangan judicial review yang diserahkan kepada dua lembaga kekuasaan yakni Mahkamah Konstitusi dan Mahkamah Agung, besarnya potensi persoalan yang dihawatirkan akan muncul dikemudain hari, maka menjadi patut kiranya mengkaji ulang model kewenangan Judicial review yang lebih ideal bangsa indonesia. Bahwa pemisahan kewenangan pengujian peraturan perundangundangan antara Mahkamah Agung dan Mahkamah Konstitusi adalah tidak ideal dan berpotensi menimbulkan problem hukum yang sangat rumit, baik dari sisi potensi terjadinya konflik putusan antara kedua lembaga peradilan tersebut, juga menimbulkan kerancuan kesetaraan kedudukan antara Mahkamah Agung dan Mahkamah Konstitusi. Sehingga kedepan perlu dirumuskan ulang dengan mengintegrasikan kewenangan pengujian peraturan perundang-undangan kepada Mahkamah Konstitusi dengan tolok ukur pengujian adalah mulai dari peraturan perundang-undangan yang lebih tinggi sampai pada konstitusi baik melalui perubahan atau penafsiran. Maka dari itu perlu adanya penerapan mengenai penyatuatapan dalam proses penyelesaian perkara judicial review yang harus dijalankan oleh lembaga kekuasaan yakni Mahkamah Konstitusi.

\section{Pustaka Acuan}

Arlinandes, M. Jeffri Chandra. Singkronisasi Norma Hukum Melalui Judicial Review di Mahkamah Konstitusi, Vol.1 No. 1, November 2017.

Asshiddiqie, Jimly. Format Kelembagaan Negara dan Pergeseran Kekuasaan dalam UUD 1945, UII Press, Yogyakarta, 2005.

Asshiddiqie, Jimly. Gagasan Dasar tentang Konstitusi dan Mahkamah Konstitusi dalam Butir-butir Pemikiran dalam Hukum, Memperingati 70 tahun Prof. Dr. B. Arief Shiddarta, SH. Penyunting Sri Rahayu Oktoberina dan Niken Savitri, Refika Aditama, Bandung, 2008.

Asshiddiqie, Jimly. Kedudukan Mahkamah Konstitusi dalam Struktur Ketatanegaraan Indonesia, Makalah Kuliah Umum di Fakultas Hukum Universistas Sebelas Maret, Surakarta, 2 September 2004.

${ }_{25}$ M. Jeffri Arlinandes Chandra, Singkronisasi Norma Hukum Melalui Judicial Review di Mahkamah Konstitusi, Vol. 1 No. 1, November 2017, h.79. 
Assiddiqie, Jimly. Pengantar Ilmu Hukum Tata Negara, Rajawali Pers: Jakarta, 2009. Assiddiqie, Jimly. Perkembangan dan Konsolidasi Lembaga Negara Pasca Reformasi, Setjen dan kepaniteraan Mahkamah Konstitusi: Jakarta, 2006.

Assiddiqie, Jimly. Sengketa Kewenangan Antar Lembaga Negara, Konstitusi Pers, Jakarta, 2006

Aji, Ahmad Mukri. Kontekstualisasi Ijtihad Dalam Diskursus Pemikiran Hukum Islam di Indonesia, Bogor: Pustaka Pena Ilahi, 2010.

Aji, Ahmad Mukri. Urgensi Maslahat Mursalah Dalam Dialektika Pemikiran Hukum Islam, Bogor: Pustaka Pena Ilahi, 2012.

https://www.hukumonline.com/berita/baca/hol10029/penyatuan-atapkekuasaankehakiman-tuntas-sebagian.

Kamaruddin, Diskursus Penyatuatapan Peradilan Agama Di Bawah Mahkamah Agung (Studi Hukum Responsif), Jurnal AL-'Adl Vol. 8 No. 1, Januari 2015.

Kusnardi, Moh; dan Ibrahim, Harmaily. Pengantar Hukum Tata Negara Indonesia, Pusat Studi Hukum Tata Negara Fakultas Hukum Universita Indonesia, Jakarta: 1983.

Maggalatung, A Salman. "Hubungan Antara Fakta Norma, Moral, Dan Doktrin Hukum Dalam Pertimbangan Putusan Hakim," dalam Jurnal Cita Hukum, Vol. 2, No. 2 (2014).

Maggalatung, A Salman; Yunus, Nur Rohim. Pokok-Pokok Teori Ilmu Negara, Cet1, Bandung: Fajar Media, 2013.

MD., Mahfud. Mengawal Arah Politik Hukum: Dari Prolegnas sampai Judicial Review, http://www.mahfudmd.com/public/makalah/makalah_26.pdf, diakses 20 Januari 2019 .

Palguna, I Dewa Gede. Pengaduan Konstitusional (Constitutional Complaint) Upaya Hukum terhadap Pelanggaran Hak-hak Konstitusional Warganegara, Sinar Grafika: Jakarta, 2013.

Qamar, Nurul. Kewenangan Judicial Review Mahkamah Konstitusi, Jurnal Konstitusi Vol. 1 No. 1, November 2012.

Safi', Urgensi Penyatuan Kewenangan Pengujian Peraturan Perundang-undangan oleh Lembaga Peradilan (Judicial Review) Di Indonesia, Jurnal Rechtidee, Vol 11 No. 2, Desember 2016.

Salia, Erli. Peran Mahkamah Konstitusi Dalam Mewujudkan Negara Hukum Yang demokratis, Makalah, Pascasarjana Ilmu Hukum Universitas Muhammadiyah Palembang. 
Muhammad Ishar Helmi

Simamora, Janpatar. Analisis Yuridis Terhadap Model Kewenangan Judicial Review di Indonesia, Fakultas Hukum Universitas HKBP Nommensen, Vol.25, No.3, Oktober 2013.

Yunus, Nur Rohim; Sholeh, Muhammad; Susilowati, Ida. "Rekontruksi Teori Partisipasi Politik Dalam Diskursus Pemikiran Politik Negara" dalam Salam; Jurnal Sosial dan Budaya Syar-i, Vol. 4, No. 3 (2017). 